\title{
Transnational elements of newcomer women's housing insecurity: Remittances and social networks
}

\author{
Nicole Ives, Jill Hanley, Christine A. Walsh, David Este
}

\begin{abstract}
Navigating settlement is complex and oftentimes stressful for international migrants. Transnational networks may provide support in addressing settlement hurdles, as may settlement or other community organizations. However, elements of the migration experience, including transnational obligations (such as remittances) and transnational networks, may also be hindrances to overcoming settlement challenges. This paper is based on a larger study on housing insecurity and homelessness among newcomer migrant women in Montreal, Canada. Here, we focus on how transnational aspects of settlement shape newcomer women's housing experiences, an understanding essential to the development of responsive services and policies. We draw on interviews with immigrant, refugee and undocumented women to illustrate the housing struggles they face, navigating transnational processes while (re)building their lives in Montreal. The paper concludes with recommendations for ways that immigrant and refugee settlement services can acknowledge and integrate these transnational considerations in order to prevent precarious housing and homelessness.
\end{abstract}

Keywords: Homelessness, transnational, housing, refugee, immigrant, remittances, social networks

\section{Introduction}

Upon arrival in a new country, migrants, whether arriving voluntarily or involuntarily, face key settlement challenges such as finding housing, acquiring/improving receiving-country language proficiency, addressing mental and physical health, finding employment, and accessing education (Ives, 2007; Miller et al., 2002; Valtonen, 2012). Navigating settlement, regardless of the way in which the migrant arrived in Canada, can be complex and oftentimes stressful. Successful navigation typically requires considerable support as challenges are complex, multiple and diverse. A migrant's transnational networks may provide support in addressing these settlement hurdles, as may settlement or other community-based, migration-focused organizations. However, elements of the migration experience, including transnational obligations and transnational networks, may also be hindrances to overcoming settlement challenges. The role of transnational networks in settlement and in reconstructing the lives of migrant women in Canada, often in the face of inequities, is an important (Spitzer, 2007) yet understudied phenomenon.

This paper is based on a larger study focused on the issue of housing insecurity and homelessness among newcomer women to Montreal, Canada. The objective of the study was to inform recommendations for programming and/or policy interventions to meet newcomer women's unique, multiple and interwoven housing needs, addressing the paucity of research directed at uncovering, exploring and understanding this phenomenon. In this paper, we focus on how transnational aspects of settlement shape newcomer women's housing experiences as this knowledge is essential to the development of responsive services and policies for this population (Sandalak, Walsh, \& Graham, 2008). We draw upon exploratory, qualitative interviews with immigrant and refugee women to illustrate the housing struggles they face as they navigate transnational processes while (re)building their lives in Montreal. The paper concludes with recommendations for ways that immigrant and refugee settlement services can acknowledge and integrate these transnational considerations in order to prevent precarious housing and homelessness.

\section{Research Context}

Locating and maintaining suitable housing has long been found to be a significant stressor in settlement; frequently there are problems of affordability, availability of appropriately sized housing and safety (Duke, 1996; Miller et al., 2002; Teixeira \& Halliday, 2010). A British study found that difficulty acquiring appropriate accommodation can have a negative impact on other aspects of settlement, such as finding a job, learning English, participating in educational or training courses, and reassembling lives (Duke, 1996). In this section, we begin by reviewing the general housing context for newcomer women before focusing on two transnational phenomena that can influence housing experiences for migrant women: (a) the role of remittances in precipitating housing crisis among newcomer 
Ives, N, Hanley, J., Walsh, C., Este, D. (2014). Transnational elements of newcomer women's housing insecurity: remittances and social networks. Transnational Social Review 4(2-3):152-167

migrants; and (b) the dual role - potentially beneficial or exploitative - of transnational networks based on ethnic origin.

\section{Housing Context for Canadian Newcomer Women.}

The housing experiences of immigrant and refugee women in Canada have been the subject of little investigation; they are typically subsumed under the broader categories of women's homelessness or newcomers' housing insecurity (see for example, Heibert, 2009; Murdie, 2008; Teixeira, 2009). Newcomers in general have higher rates of poverty (Galabuzi, 2006), higher vulnerability to precarious employment (Vosko, 2006) and are more likely than the Canadianborn population to spend more than half of their household incomes on housing (Hiebert, 2009; Rose, 2001), much of which is inadequate (Leloup \& Zhu, 2006) and situated in declining neighbourhoods (Carter \& Osborne, 2009). Housing insecurity for newcomers has been linked to strains on social networks, limited social capital (D'Addario et al., 2007) and isolation and social exclusion (Danso, 2002; Ray \& Preston, 2009).

Canadian studies indicate that migrant women report higher rates of personal and housing discrimination than migrant men (Dion, 2001; Paradis, 2012). When compared with newcomer men or Canadian-born women, immigrant and refugee women have higher rates of poverty (Canadian Association of Social Workers, 2004; Saraswatisi, 2000), are more interpersonally dependent (Neufeld et al., 2002), have greater childcare responsibilities (Tischler, Rademeyer, \& Vostanis, 2007), and experience higher rates of social exclusion and isolation (Omidvar \& Richmond, 2003). Housing difficulties are also a primary barrier to the integration process of young immigrant women (Centre d'encradrement pour jeunes filles immigrantes [CEJFI], 2004; Paradis, 2012).

Homeless women migrants are marginalized by their invisibility (Fiedler, Schuurman, \& Hyndman, 2006). Newcomers face barriers to emergency or temporary shelters such as language difficulties and lack of culturally appropriate services (Shirwadkar, 2004; Supporting Communities Partnership Initiative, 2003). Unlike Canadian-born women, refugee and immigrant women have significantly fewer resources to deal with the onset of homelessness and a lack of familiarity with both Canadian culture and potential services (National Anti Poverty Organisation, 2004). Instead, they resort to strategies designed to remediate the risk of absolute homelessness, including sharing accommodation, couch-surfing, and relying on their social contacts for temporary and precarious housing (Anucha et al., 2007; Kilbride et al., 2006; D’Addario et al., 2007).

Research generated by local housing and women's organizations describes the dynamics contributing to housing difficulties for newcomer women in Montreal. Within the context of changing economic and housing environments, immigrant and refugee women in Montreal face significant challenges (Conseil des Montréalaises, 2007). The CEJFI (2004) and Auberge Madeline (Smith, 2003) identify the multiple barriers faced by immigrant women in Montreal seeking to establish secure housing including: racism; language difficulties; unemployment and consequent poverty; lack of recognition for professional qualifications; experience or skills; the absence of support structures; the effects of prior trauma (especially in the case of refugees); loss of family members; difficulties with settlement in a new country; lack of child care services; difficulties in adapting to a new climate; and intergenerational conflict. Housing difficulties are a primary barrier to the integration process of young immigrant women (CEJFI 2004).

A Quebec-based housing advocacy organization (Front d'action populaire en réaménagement urbain [FRAPRU], 2010) reported that a lack of credit history and Canadian employment history or references, the presence of children, or visible minority status prevented many immigrant women from being accepted by landlords in the province of Quebec. Given this strong discrimination, it follows that immigrants make up an increasing proportion of women seeking shelter services in Montreal as the number of immigrants to Quebec has increased. In a report for Quebec's Commission des affaires sociales, a Montreal women's shelter la Rue des Femmes identified a significant increase $(25 \%)$ in immigrant and refugee women participating in their day program or seeking shelter. This increase is even higher in shelters that accept women with children (La Rue des femmes, 2008).

\section{Transnationalism and housing outcomes: the role of remittances and social networks.}

It is well established that most migrants reside in a transnational space, unless they have severed all ties with their country of origin and have no contact with expatriate community members. For the purposes of this paper, transnationalism is defined as the ways in which migrants "forge and sustain multi-stranded social relations that link together their societies of origin and settlement" (Basch, Glick Schiller, \& Szanton-Blanc, 1994: 7), whether they literally make frequent returns to the home society or, more figuratively, sustain economic and emotional connections with the country of origin without necessarily traveling there in person (Lim, 2009). 
Ives, N, Hanley, J., Walsh, C., Este, D. (2014). Transnational elements of newcomer women's housing insecurity: remittances and social networks. Transnational Social Review 4(2-3):152-167

Recent research on transnationalism among forced migrants reveals these processes' interrelatedness and intricacy with regard to how transnational practices function for migrants as well as families in the country of origin (Boyle \& Ali, 2010). However, settlement services, particularly in Canada and the US, still operate on a traditional model that emphasizes the need for self-sufficiency and does not take into account obligations or pressures a migrant may have in the home country. Particularly in cases of forced migration, migrants' personal obligations that influence transnational motivations and practices are attenuated (Lim, 2009). A recent study in Montreal on homelessness among migrant women found that financial insecurity, immigration status, physical illness and exploitation by landlords and fellow ethnic community members were central reasons for ongoing housing insecurity (Walsh, Hanley, Ives, Hordyk, \& Mahano, 2011). Transnational processes that played a significant role in migrants' housing experiences were remittances and transnational social networks.

Considerable research has been conducted on the impact of remittances on migration source countries, particularly from a development perspective (e.g., Nyberg-Sørensen, Van Hear, \& Engberg-Pedersen, 2002; Papademetriou \& Martin, 1991; Russell, 1992). More recently, focus has turned to remittance senders themselves, how much is sent, how remittances alter the lives of those who send and those who receive, and the types of stresses that transnational networks place on migrants as they struggle to fulfill their own needs and those of their nuclear and extended families in their country of origin (Hammond, 2011, 2013; Lim, 2009; Lindley, 2009, 2011; Riak Akuei, 2005). This reciprocal relationship is emphasized by a reminder that "remittances should be seen as part of an exchange; it is in this link between home and abroad that 'transnationalism' lies" (Van Hear, 2002: 202-203).

Remittances are a billion dollar industry, which has grown tremendously in the last several decades. In 1980, migrant remittances were estimated globally at US $\$ 43.3$ billion; twenty years later, remittances increased to US $\$ 100$ billion in 2000 (Gammeltoft 2002; Guarnizo, 2003). Analyzing World Bank data from 2010, Portes and Zhou (2012) found that only eight years later, in 2008, officially recorded remittances to developing countries reached $\$ 336$ billion, with the major recipients of migrant remittances being India ( $\$ 49$ billion), China ( $\$ 48$ billion), Mexico ( $\$ 22$ billion), and the Philippines ( $\$ 20$ billion). In some instances, the process of sending remittances can be highly organized, such as in cases where governments of migrant-sending countries form offices and programs that reinforce connections with their expatriates (Portes \& Zhou, 2012). In other cases, remittance-sending is carried out by individuals, families, and communities more directly, with no government intervention. Migrants utilize money-sending systems, either global entities, such as Western Union, or more local systems, such as xawilaada, a money-transfer system used by the Somali diaspora. The vast majority of remittances sent to home countries go to individual households to cover basic necessities or to address certain unique expenses (Hammond, 2011).

With a shifting focus from recipient to sender, research has highlighted the extent to which remittances shape transnational social ties. Looking at the Somali context, Hammond (2011) notes that from one perspective, remittances can solidify social ties as well as form new connections between extended family and communities in the country of origin, where remittances may serve to "negotiat[e] or creatively reinterpret social relationships" (126). However, Hammond notes that from another perspective, a migrant's "inability or failure to remit can weaken social ties, sow the seeds of conflict, and ultimately result in the alienation of the sender from those who expect support as well as from fellow clan members or members of the diasporic community" (126). Family in the country of origin often have little understanding of the financial pressures faced by migrants in the destination country (Riak Akuei, 2004). Thus, remittances can be a heavy financial burden for newcomer migrants, forcing them to work multiple jobs or to take difficult jobs that others do not want, compounding poverty (Lindley, 2013). Additionally, research has also found a growing "feminisation of participation" in remittance practices (Lindley, 2009: 1322), which can put severe financial strain on women migrants particularly if they are also sole caregivers for children or other family members (Hammond, 2011).

Turning to our second factor, social networks are key to the process of migrant adaptation in a receiving society, whether they are sets of interpersonal links generated by kinship, friendship, or shared national, ethnic, and cultural origin (Ives, 2007). According to Portes (1995), these networks represent an important source of social capital. For example, migrants facing barriers in the job market may turn to self-employment with the support of ethnic networks and ethnic resettlement services. Having access to the practical and psychological support of family, community members, and other informal ethnic networks in the receiving society has also been found to decrease mental health problems among refugee victims of sexual violence (Schei \& Dahl, 1999) and decrease stress levels which in turn reduce the intensity and likelihood of mental illness in the refugee population (Rousseau et al., 1998; Schwarzer, Jerusalem, \& Hahn, 1994; Valtonen, 2012). In her study of the integration of refugees from the former Yugoslavia, Korác (2001) focused on the characteristics of social networks developed by these refugees in Rome and their efforts to become self-sufficient and independent in a limited amount of time. For women with limited social networks in the a receiving society, the lack of familiarity with neighborhoods, housing and rental norms and prices, 
for example, makes them targets for exploitation and discrimination on the private housing market (Walsh et al., under review).

However, even though the availability of both informal and formal social networks has been found to be essential to resettlement, having access to social networks may be a positive or a negative factor. Goss and Lindquist (1995) cautioned against the idealization of community that ethnic networks often represent. So while social networks based on country of origin could assist newcomers with finding housing and navigating the circuitous path of settlement and public assistance services, Walsh and colleagues (under review) found that membership in such social networks did not preclude newcomers from exploitation at the hands of fellow expatriates. Some migrants experienced abuse as a result of their transnational ties. As with other social phenomena, ethnic networks are socially dynamic and can be benign, supportive or exploitative, depending on the relationships and characteristics of the individuals or groups involved.

\section{Methods}

This Montreal-based study was designed with two key ideas as a conceptual framework. First, housing insecurity is a gendered phenomenon (Walsh et al., 2009). Second, the direct experiences of persons with insecure housing need to be heard to inform solutions (Acosto \& Toro, 2001; Walsh et al., 2010). We wanted to capture the diversity of immigrant women's experiences, so we adopted an exploratory, qualitative, methodological approach, using a definition of housing insecurity that spanned the spectrum from absolute homelessness (e.g., residing in shelters), to invisible homelessness (e.g., living with friends or family) to those at risk of homelessness (e.g., living in substandard housing or at risk of losing their homes; Ben Soltane et al., 2012; Echenberg \& Jensen 2008; Girard 2006).

Semi-structured, open-ended interviews lasting approximately one hour were administered to a sample of 26 newcomer women in Montreal, Canada, in 2011. We defined newcomer women as foreign-born women who came to Canada in the last 10 years, regardless of their immigration status. To participate in the study, women had to selfidentify as having experienced housing insecurity. Women were recruited directly through advertisements in public places as well as in collaboration with community organizations: women's centers, homeless shelters, crisis centers, domestic violence shelters, immigrant settlement agencies and ethnic associations. An effort was made to recruit women with a diversity of immigrant statuses -- permanent residents, temporary foreign workers, refugee claimants and undocumented women - and diversity in ethnicity, race, and country of origin, family composition, sexual orientation, age, and range of physical and mental ability. Participants were given a small honorarium for their participation and reimbursed for any travel and childcare expenses. The interview location and time varied according to participant need and interviews were conducted in either English or French, depending on the participant's preference. Once participants had given informed consent, the interview questions focused on five themes: (1) current demographics and immigration history, (2) current health and well-being, (3) history of housing and home insecurity, (4) current situation and (5) survival strategies.

In addition, researchers conducted face-to-face interviews with five key informants working in four local women's shelters. The semi-structured, open-ended questions were designed to gather information about newcomer women's homelessness or housing insecurity from a service provider's perspective. They were asked to describe best practices and challenges in serving the target population. All interviews were transcribed, coded with NVIVO software and then analyzed using the constant comparative method (Dye et al., 2000).

\section{Results: Transnational Elements of Newcomer Women's Housing Insecurity}

The factors contributing to insecure housing were portrayed by newcomer women and shelter workers alike as complex, multiple and interrelated at the political, social and personal levels. While we have discussed some of these factors elsewhere (see Walsh et al., 2011; Walsh et al, under review), here we wish to highlight two factors that transcend Canadian borders, linking newcomer women to their countries of origin through on-going relationships and past experiences. The resulting housing challenges illustrate the degree to which being transnational influences newcomer women's struggles to find stability and security in Canada. We begin with a discussion of the degree to which remittances undermine newcomer women's ability to pay for decent housing. We then explore the complex web of transnational social networks that can both help and hinder newcomer women in housing need.

\section{Remittances.}

Of little surprise in this study was that newcomer women reported poverty to be the main reason that they experienced housing insecurity or homelessness. The women in our study faced unemployment, low-paying jobs and social 
assistance rates that make it impossible to make ends meet; consequently, they found themselves living in poverty. While poverty is obviously a factor shared with Canadian-born women facing housing insecurity or homelessness, the phenomenon of remittances is generally not. This additional economic responsibility for immediate and/or extended family left behind in the country of origin is one that the women in our study were aware set them apart from most Canadians, as we see in one participant's explanation:

I am responsible also to take care of my family back home... You always feel this responsibility of sending the money to your loved ones who don't even have what you have here. First of all, because they don't have a job. Second of all, because of the insecurities, they can't hold a job. And thirdly, that's just how it is. They think you are here and that you've got all of this money. So you have to live up to their expectations. So, I had to work, and I had to work, and I had to work. I had to work all of the time...

This participant, a single woman, lived a period of absolute homelessness in part because she preferred to send money back to her family living in an armed conflict zone than to spend what little money she had on an apartment. After losing her live-in homecare job (and therefore her housing), she described feeling guilty spending money on herself apart from subsistence needs when she knew her family in her country of origin lived with such great insecurity without any possibility of joining her in Canada.

While not all newcomer women's families were living in such dire socio-political contexts as the refugeeproducing situation above, simple poverty in their home country was ample pressure for many participants to endure hardship. Large families in the country of origin may have many needs, without necessarily much understanding of the reality faced by their expatriate family members. In many cases, family members had supported their migration, creating an even greater sense of obligation and responsibility, as described by this participant:

My husband was lucky to have a job [in Canada], but the job was not well paid and me and my child we all depended upon his meagre income... My husband was taking care of his whole family. My family also needed us as well. My father is retired; my mother was not working... And since I am the first born of five siblings, they spent some money on my education, hoping I will be taking care or I will help them take care of my younger ones. My juniors were depending on me... My husband was the second born of his family, in a family of eight children, so it was really hard for us to live on that one salary.

The debt described above is felt as a moral obligation, but in some cases newcomer women reported having monetary debt with their families back home. Their families may have made great sacrifices to help them study and migrate, often by pooling scarce resources, and consequently they felt great pressure to pay them back:

My husband did not have enough money so we even had to borrow from our family members to help us get here. You have to pay a flight for three people, filling up all kinds of forms as well as medical check-ups and all of that. So, the money was not there for us... My father had a small piece of land; he volunteered to give us the land, which we ended up selling to help us get enough money for the processing of our papers. So, we sold the land on the condition that if we get here, we have to give back the money to him so he could by another land. So it's as if he lent us money that we have to pay him back, but the only good thing is that we don't have to pay interest since it is my father that gave us the land...

Even when the situation in Canada takes a really difficult turn, family members left behind may find it impossible to understand their family member's challenges in sending money home. The pressure to send remittances remains and can often ends up straining relationships with loved ones, as we hear from this participant who lost her husband to cancer soon after their arrival in Canada:

Back home they are still relying on me too to help them, you understand me? Even though I am now a widow, they still think I am better off and that I can help them. They call me every day. They themselves, they are very poor; they think I am better off than them, so I do not blame them. They can barely eat... It's just that I have tried to explain my situation to them, so they can understand me, but sometimes they just can't understand. I just tell them I am still a student. As soon as I am done with school, things will be better and hopefully I can help them. The worst part is the rent. I don't sleep at night. As soon as I get the rent paid, at least I can have some peace. If the rent is paid, I would call friends for food, for clothing.

As articulated in this quote, the accumulation of such responsibilities results in difficulties maintaining housing. The women in our study continued to feel financial responsibilities that transcended borders, linking them to families in far-away places yet making it challenging to cover all their expenses - including those for housing - in 
Ives, N, Hanley, J., Walsh, C., Este, D. (2014). Transnational elements of newcomer women's housing insecurity: remittances and social networks. Transnational Social Review 4(2-3):152-167

Canada. These transnational responsibilities thus appeared to interfere with their long-term ability to achieve some form of sustainable integration in Canada.

\section{Social Networks.}

A second recurring theme in our interviews was a strong attraction to social networks linking women's new lives in Canada to the community they left behind in their country of origin. In many cases, women arrived in Montreal with referrals and contact information for distant relatives or friends of friends who were already settled here. These expatriate networks were expected to be sources of help and support as women looked for housing and got organized in their new city. Apart from these networks, women also described being drawn to strangers whom they heard speaking their language or were presumed to be from the same ethnic group. Again, there was an assumption that because this person came from the same country or region of origin, he or she would be an ally if the women were experiencing difficulties, would be a source of information and advice, and potentially would be new friends. As we will see in the cases below, these transnational social networks were sometimes able to play a very positive role in helping women face housing insecurity. However, such social networks could work against them as a source of exploitation, exploitation that the women often experienced as deep betrayal.

Members of these transnational social networks were often the first source of shelter for newly arrived women, helping them to secure their first apartments. The assistance could be very generous, as related by this woman, and could be the first step towards their goals in coming to Canada:

He just offered to pay rent for me the first month - just like that - because I knew him from Africa. He looked for the apartment for me and paid the rent, and fortunately for me, during that period, I got my work permit. So, when I got my work permit, I started to look for a job. So I found a job in a factory, and I started working.

Friends or family would sometimes open their homes to their compatriots for the first few weeks as the newcomers sought their own housing and employment. Although the help was much appreciated and needed, many women reported feeling uncomfortable:

I am staying with this family, and I am constantly worried about distracting their family flow. They have young kids. The kids are in school but, nonetheless, little kids need their sleep. Mom and dad, they both work... And I have a new-born baby waking people up. So the little kids were really sweet with me... They are sleeping with mommy and daddy. So four people are now sleeping in the same bed so that me and my baby, we can have our own room. So the guilt in knowing you are displacing people was making me uncomfortable. These little children were bending to accommodate the problems that I have created for myself... You see, I am touched by all of this. These kids are literally being kicked out their room for me and my baby.

In some cases, the friends with whom the participants were staying were in financial situations just as difficult as they were, also experiencing housing insecurity:

My friend's husband was just struggling to survive too. He did not have a job and my friend was often home with the child. My friend's husband was working in a factory and was getting minimum wage but then he lost the job before we arrived. It was not easy. And my husband was not working either so they were basically feeding us in their home with their meagre income they had. We understood because they were barely surviving, and especially that we did not have anything to contribute once our food run out, so we just had to survive.

Tensions could arise and more than one woman described being evicted with short notice from a friend or family member's home when the resources became too tight, patience dissolved and conflicts erupted. This sudden loss of shelter led some women to be absolutely homeless until they could get reestablished.

In the worst-case scenarios, members of these transnational social networks were the source of problems when newcomer women were seeking help. For many, accessing these networks served only to alleviate the immediate housing need but did not contribute to finding sustainable housing. One participant described a chance meeting with a woman from her country of origin, which led to subleasing an apartment: 
Ives, N, Hanley, J., Walsh, C., Este, D. (2014). Transnational elements of newcomer women's housing insecurity: remittances and social networks. Transnational Social Review 4(2-3):152-167

I was just looking for something I could afford even though it was not in a safe neighbourhood. Likely enough, I came across this lady from [country of origin] ...Apparently she was also looking for someone to rent her apartment. . . She wanted to sublet her apartment... I didn't really like it, but I had no choice given that I didn't know Montreal that well and the craziness of canvassing around in between apartments was just not fun. I stayed in that apartment for about one year. And because this was a basement, it was often cold especially in winter. The landlord never put on the heater in the basement so, every time I would come home, the only place that was warm was in my bed. . . . One time I bought myself small electric heater, and the landlord found out that I was using it, he was very mad. He got so mad that he was threatening to throw me out of his house, which I could not afford at the time. I would sometimes try to stay out, in libraries especially, not because I wanted to read, but because it was warmer than going home.

In some cases, accessing these networks actually put women in physical danger. While all participants described feeling frustration with local landlords regarding housing issues, it was most painful for participants to describe being exploited by fellow expatriates. Several women had strong reactions when recounting these stories, recalling a keen sense of betrayal. For example, the participant below initially trusted a couple from her country of origin, who helped her when she arrived in Montreal:

...Every week I worked, they promised to give me room and board before I could get my own house. I thought it was a good deal since I did not have anywhere to stay. I felt protected living with people who have been in this country for a long time. They knew all the rules and these are people from my own place, so I felt safe to be with them. I thought they would be willing to protect me and show me what is good for me, so I trusted them at the time. I worked, so they told me they would keep my money for me. So I continued to work, not getting my pay. Then when I started asking for my money, they started becoming angry at me, and you know, they became very abusive. It was very difficult.

A number of women reported economic exploitation, emotional abuse and sexual harassment or assault by members of transnational social networks who offered to house them when the women were in situations of homelessness or extreme housing insecurity. The women initially trusted these apparent helpers and felt shame to have been betrayed by a person with potential connections to their family or other members of their community. This participant initially stayed with a friend from her country of origin, with whom she had a relationship. However, she was only able to stay a few months as the relationship became violent.

I was with a friend of mine from [country of origin] who bring me up here, a guy. It's no good...He said, I may come up here. [I lived with him until] around Christmas. At Christmas, then I went Toronto... Yeah, he didn't know.

He didn't know?... So you had to sneak out?

Yeah.

Was it a violent situation?

Yeah...I don't like that about it. He did make me... cry.

She was able to stay temporarily with a brother but then when she was not working and unable to contribute to the rent, it caused conflict. Another participant came to Montreal fleeing from an abusive situation in another province; her challenges, however, continued:

When I came, I didn't have anything... I didn't know about any resources, so I called [a family friend from a country bordering her country of origin living in Montreal] and said, "I have just moved here and I want to find a job eventually but if you can house me for maybe a few days, until I find myself a place to live." I lived with this guy for about maybe two weeks, and I was going around looking for apartment. Well, I didn't know where. I was taking the metro to anywhere. I was using [a local] library... I would go every morning and try to find an apartment on Internet. I travelled to places most of which I didn't know. [At] this time, security was not a concern. [The man] on the other hand, had begun making moves on me. He started touching me inappropriately. He began to be disrespectful towards me because I have refused to smoke marijuana with him. The tone in the house changed and I knew I had to find myself another place before he 
locks me outside his house. So I was really desperate in finding something, just anything. I didn't worry anymore about security. I was in dire need to move out from that house.

As we see in these examples taken from our interviews, social networks based on ethnic or national affiliations can have very strong positive or negative influences on newcomer women's housing experiences. Upon arrival in a new place, women often turn to these networks first for information or assistance. In the best scenarios, members of these networks offer generous support and start newcomer women along a path of settlement and security. When women are truly vulnerable, however, such networks can be a place where trust is misplaced and where such trust can be devastatingly betrayed.

\section{Discussion}

While many of the efforts to address housing problems in general will also be of use to newcomer women, it is essential to take into account the ways in which their migration trajectory may influence their overall housing experience, with transnational processes such as remittance-sending and reliance on ethnic and national social networks coming to the fore. Gender is a twin consideration in this equation as women are overrepresented in precarious status immigration programs, making them at the same time more vulnerable to exploitation and less eligible for public aid (Hanley \& Shragge, 2009).The women's heightened dependencies (economic, relational, legal), linked with their heavier responsibilities for child rearing, made their experiences of housing insecurity different from men's.

As in previous studies, remittances played a central role in participants' ability to locate and sustain affordable and safe housing. Remittances were also significant for participants who came to Canada as refugees, although their reason for flight was based on persecution in the country or origin rather than for the purpose of diversifying household income sources (Lindley, 2001). Thus, for migrants, moving out of poverty in the settlement country can be jeopardized by addressing the poverty of family and community in the country of origin. Moreover, as many participants noted, migrants may not want to reveal the grim reality of their situations to family in the home country, glossing over the difficulties they are facing. Al-Ali, Black and Koser (2001) noted that this only serves to "reproduce distortions and misconceptions about refugees' lives and material conditions in the receiving countries" (592).

Remittances serve not only an economic function but social and cultural functions as well. While remittances can cover daily basic necessities as well as event-specific emergencies, they are also a way of maintaining social and cultural connections with the country of origin. Lim (2009) found that Sudanese refugee study participants were motivated by what they termed as the Sudanese value of sharing, equating remittances with a cultural trait. Therefore, cultural values were maintained in the settlement country and social ties could be strengthened through the fulfillment of financial obligations, what Lindley (2011) termed "cultural and familiar reaffirmations" (53).

Our study also confirmed that transnational elements of the migration process could help or be a hindrance (e.g., Hammond, 2011; Lim, 2009; Lindley, 2009, 2011), in this case in terms of housing. Social networks provide critical support to migrants, particularly the processes of social and economic integration (Ahearn, 2000; Korác, 2001; Mestheneos \& Ioannidi, 2002; Rousseau et al., 1998). On an individual level, social networks provide informal assistance, compassion, and information from family, friends, kin, community, and ethnic groups (Van Hear, 1998). Having available informal support from relatives, friends, and the local community can provide opportunities for assistance with housing and employment and help in addressing various resettlement issues and relieving social isolation. Numerous participants described the positive assistance they received from expatriates from their country or region of origin. This assistance in many cases was instrumental in finding housing, although for some, the housing was only temporary.

Study findings, however, served as a reminder that not all social networks have positive utility. Many compatriots were in only slightly better circumstances economically than participants. Some chose to help participants to the extent that they were able, while others chose to exploit the vulnerability of women migrants in the study, using participants' lack of knowledge of the local context and of their legal rights to take advantage of them, economically, emotionally and physically. The fact that this abuse was coming from people that newcomer women expected to be supportive was all the more devastating for them.

\section{Implications for Settlement Services}

This study identified some recurring themes related to the improvement of policy and services for this population. While there are limits to the generalizability of our findings given the small sample and short timeline of this study, we have identified two main areas for development: (1) training on newcomer women's transnational realities for the 
two sectors most involved with this population: housing organizations and settlement services and (2) wrap-around services in terms of health, housing and immigration settlement. Lindley (2011) calls for greater attention to the distinct pressures faced by remittance senders. Ignoring these pressures and/or obligations of migrants to remit ignores a central facet of their settlement experience, and, for the participants in our study, jeopardized their ability for safe, sustainable housing. Likewise, a lack of attention to the possible role of transnational social networks can lower the effectiveness of settlement work. The positive contribution of transnational social networks should not be taken for granted. Settlement policy and programs should take heed of these realities when considering assistance.

While recruiting participants for our study, we spoke with representatives of housing organizations who identified their own lack of expertise regarding other domains such as immigration policy and migration experiences. They were unfamiliar with the concept of remittances as a significant factor in many migrants' monthly budgets, one that greatly limits the income available for rent. Immigration settlement organizations, while responsible for helping immigrants and refugees with housing searches, were aware that they knew little of newcomers' experiences once in housing and of how their transnational migration realities might be intersecting with their housing experiences. Thus, when women found themselves in substandard housing or without the means to pay their rent, there was little the settlement agencies could do. Both sectors of service organizations were interested in receiving training on these issues and were eager to increase communication and cooperation between these sectors. This would be a first step towards wrap-around services for migrant women.

For most newcomer women, immigration settlement agencies are their first contact, so this seems a logical place to begin in the prevention of housing insecurity. We were struck by how many women expressed a sense of being lost when faced with a list of housing advertisements and a telephone. For women with limited social networks in the city, the lack of familiarity with neighborhoods, housing and rental norms and prices, among other things, makes them ripe for exploitation and discrimination on the private housing market or by members of ethnic and national communities. Actual accompaniment in the housing search would have made a considerable difference in many women's experience, helping them to avoid bad situations in the first place. Apart from the need for more housing services within immigration agencies, more resources are needed, such as settlement caseworkers who can assist women to identify and address their other needs in terms of health care, education and child care.

Finally, newcomer women repeatedly told us "I had nowhere to go." The women we interviewed often did not conform to the mandate of available shelters: absolute homelessness or victims of domestic violence. Many were simply poor, socially isolated, and dealing with multiple stressors. Access to longer-term transitional housing intended to support newcomers would have been a major help. However, recent restrictions such as the changes to the Interim Federal Health Program for refugee claimants have reduced federally mandated service to this population (Fitzpatrick, 2012). One model that seems appropriate is the long-term transitional housing offered to young mothers. It offers stability and security to women who find themselves in a difficult and unfamiliar situation, while offering them access to support services (e.g., education, employment training, trauma counselling) that can produce better outcomes. For many newcomer women with housing insecurity, having a year or more of such housing could interrupt the trajectory of dislocation and chronic need. 
Ives, N, Hanley, J., Walsh, C., Este, D. (2014). Transnational elements of newcomer women's housing insecurity: remittances and social networks. Transnational Social Review 4(2-3):152-167

\section{References}

Acosta, Olga/Toro, Paul A. (2000): "Let's Ask the Homeless People Themselves: A Needs Assessment Based on a Probability Sample of Adults. In: American Journal of Community Psychology 28, 3, pp. 343-366.

Ahearn, Frederick L. (ed.) (2000): Psychosocial Wellness of Refugees: Issues in Qualitative and Quantitative Research, Vol. 7. New York: Berghahn Books.

Al-Ali, Nadje/Black, Richard/Koser, Khalid (2001): The Limits to "Transnationalism": Bosnian and Eritrean Refugees in Europe as Emerging Transnational Communities. In: Ethnic and Racial Studies 24, 4, pp. 578-600.

Anucha, Uzo/Smylie, L., Mitchell, C., \& Omorogon, F. (2007). Exits and returns: An exploratory longitudinal study of homeless people in Windsor-Essex County. (Ottawa, ON: Canada Mortgage and Housing Corporation, Research Report.

Basch, Linda/Glick Schiller, Nina/Szanton Blanc, Cristina (1994): Nations Unbound. Transnational Projects, Postcolonial Predicaments and Deterritorialized Nation-States. London: Routledge.

Ben Soltane, Sonia/Hanley, Jill/Hordyk, Shawn-Renee (Fall 2012): Révéler l'Itinérance des Femmes Immigrantes à Montréal : Documenter l'Itinérance Différemment. In: Revue FéminÉtudes 17.

Boyle, Elizabeth Heger/Ali, Ahmed (2010): Culture, Structure, and the Refugee Experience in Somali Immigrant Family Transformation. In: International Migration 48, 1, pp. 47-79.

Canadian Association of Social Workers (2004). Women's income and poverty in Canada-revisited. Retrieved: http://caswacts.ca/advocacy/womenpoverty_e.pdf

Carter, Thomas S./Osborne, John (2009): Housing and Neighbourhood Challenges of Refugee Resettlement in Declining Inner City Neighbourhoods: A Winnipeg Case Study. In: Journal of Immigrant and Refugee Studies 7, 3, pp. $308-327$.

Centre d'encradrement pour jeunes filles immigrantes (CEFJI) (2004) : Pour une Journée Québecoise des Filles Immigrantes. Montreal, Quebec.

Conseil des Montréalaises (2007): Les femmes et le logement à Montréal. Retrieved from ville.montreal.qc.ca

Danso, Ransford (2002): From 'There' to 'Here': An Investigation of the Initial Settlement Experiences of Ethiopian and Somali Refugees in Toronto. In: GeoJournal 56, 1, pp. 3-14.

D'Addario, Silvia/Hebert, Daniel/Sherrill, Kathy (2007): Restricted Access: The Role of Social Capital in Mitigating Absolute Homelessness among Immigrants and Refugees in the GRVD. In: Refuge 24, 1, pp. 107-115.

Dion, Kenneth L. (2001): Immigrants' Perceptions of Housing Discrimination in Toronto: The Housing New Canadians Project. In: Journal of Social Issues 57, 3, pp. 523-539.

Duke, Karen. (1996): The resettlement experiences of refugees in the UK: Main findings from an interview study. In: New Community 22, pp. 461-478.

Dye, Jane F. /Schatz, Irene M. /Rosenberg, Brian A. /Coleman, Susanne T. (2000): Constant Comparison Method: A Kaleidoscope of Data. In: The Qualitative Report 4, 1/2, pp. 1-9.

Ehrenberg, Have/Jensen, Hilary (2008): Defining and enumerating homelessness in Canada. Ottawa, ON: Parliament of Canada. Retrieved from: http://www.parl.gc.ca/Content/LOP/ResearchPublications/prb0830-e.htm

Fiedler, R. /Schulman, N. /Hyndman, J. (2006): Hidden Homelessness: An Indicator-Based Approach for Examining the Geographies of Recent Immigrants At-Risk of Homelessness in Greater Vancouver. Cites 23, 3, pp. $205-216$.

Front d'action populaire en réaménagement urbain (FRAPRU). (2010). Femmes, Logement et Pauvreté. Retrieved from www.frapru.qc.ca

Fitzpatrick, M. (2012, April 25): Refugee Health Benefits Scaled Back by Tories. Retrieved from: http://www.cbc.ca/m/touch/news/story/2012/04/25/pol-refugees-health-coverage.html

Galabuzi, Grace Edward. (2006): Canada's economic apartheid: The social exclusion of racialized groups in the new century. Toronto: Canadian Scholars' Press.

Gammeltoft, Peter (2002): Remittances and other financial flows to developing countries. In: International Migration 40, 5, pp. 181-211.

Germain, Annick (2009): A Closer Look at Montréal: Is the Housing Situation for Immigrants Becoming More Precarious? In: Canadian Geographer / Le Géographe canadien 53, 3, pp. 342-344.

Girard, Marie-Chantal (2006): Determining the Extent of the Problem: The Value and Challenges of Enumeration. Canadian Review of Social Policy 58, pp. 101-107.

Goss, Jon/Lindquist, Bruce (1995): Conceptualizing International Labour Migration: A Structuration Perspective. In: International Migration Review 29, pp. 317-51.

Guarnizo, Luis Eduardo. (2003): The Economics of Transnational Living. In: International Migration Review 37, pp. 666-699.

Hammond, Laura (2013): Somali Transnational Activism and Integration in the UK: Mutually Supporting Strategies. In: Journal of Ethnic and Migrations Studies 39, 6, pp. 1001-1017.

Hammond, Laura (2011): Obliged to Give: Remittances and the maintenance of transnational networks between Somalis at home and abroad. In: Bildhaan: An International Journal of Somali Studies 10, 1, pp. 125-151.

Hanley, Jill/Shragge, Eric (2009): Economic Security for Women with Precarious Immigration Status: Enforcing Labour Rights for All. In J. Pulkingham \& M. Griffin Cohen (Eds.), Imagining Public Policy to Meet Women's Economic Security Needs. Toronto: University of Toronto Press.

Hiebert, Daniel (2009): Newcomers in the Canadian housing market: A longitudinal study, 2001- 2005. In: Canadian Geographer/ Le Géographe canadien 53, 3, pp. 268-287.

Holstein, James A./Gubrium, Jaber F. (eds.) (1995): The Active Interview, Vol. 37. Thousand Oaks, CA: Sage. 
Ives, N, Hanley, J., Walsh, C., Este, D. (2014). Transnational elements of newcomer women's housing insecurity: remittances and social networks. Transnational Social Review 4(2-3):152-167

Ives, Nicole (2007): "More Than a "Good Back": Looking for Integration in Refugee Resettlement. In: Refuge: Canada's Journal on Refugees 24, 2, pp. 54-63.

Kilbride, Kenise Murphy/Webber, Steven M./Wong, Cecilia/Amaral, Nelson (2006): Plug Them In and Turn Them On: Homelessness, Immigrants and Social Capital. Ottawa, ON: Housing and Homelessness Branch, Human Resources and Social Development Canada.

Korác, Maja (2001): Cross-Ethnic Networks, Self-Reception System, and Functional Integration of Refugees from the Former Yugoslavia in Rome. In: Journal of International Migration and Integration 2, pp. 1-26.

Leloup, Xavier/Zhu, Nong (2006) : Différence dans la Qualité de Logement: Immigrants et Non-immigrants à Montréal Toronto et Vancouver. In: Journal of International Migration and Integration 7, 2, pp. 134-166.

Lim, Soh-Leong (2009): "Loss of Connections is Death". Transnational Family Ties Among Sudanese Refugee Families Resettling in the United States. In: Journal of Cross-Cultural Psychology 40, 6, pp. 1028-1040.

Lindley, Anna (2013): Diaspora and Transnational Perspectives on Remittances. In Ato Quayson \& Girish Daswani (Eds.), A companion to diaspora and transnationalism (pp. 316-329). Malden, MA: Blackwell.

Lindley, Anna (2011): The North-South Divide in Everyday Life: Londoners Sending Money Home. In: Bildhaan: An International Journal of Somali Studies 9, 1, pp. 39-62.

Lindley, Anna (2009): The Early-Morning Phonecall: Remittances from a Refugee Diaspora Perspective. In: Journal of Ethnic and Migration Studies 35, 8, pp. 1315-1334.

Mestheneos, Elizabeth/Ioannidi, Elizabeth (2002): Obstacles to Refugee Integration in EU States. In: Journal of Refugee Studies, 15, pp. 304-320.

Miller, Kenneth E./Worthington, Gregory J./Muzurovic, Jasmina/Tipping, Susannah/ Goldman, Allison. Bosnian Refugees and the Stressors of Exile: A Narrative Study. In: American Journal of Orthopsychiatry 72, 3, pp. 341-354.

Murdie, Robert (2008): Pathways to Housing: The Experiences of Sponsored Refugees and Refugee Claimants in Accessing Permanent Housing in Toronto. In: Journal of International Migration and Integration 9, 1, pp. 81-101.

National Anti-Poverty Organization (2004). Voices: Women, poverty and homelessness in Canada. Ottawa: NAPO/ONAP.

Neufeld, Anne/Harrison, Margaret J./Stewart, Miriam J./Hughes, Karen D./Spitzer, Denise (2002): Immigrant Women: Making Connections to Community Resources for Support in Family Caregiving. In: Qualitative Health Research 12, 6, pp. $751-768$.

Nyberg-Sørensen, Ninna/Van Hear, Nicholas/Engberg-Pedersen, Poul (2002): The Migration-Development Nexus: Evidence and Policy Options. In: International Migration 40, 5, pp. 49-73.

Omidvar, Ratna/Richmond, Ted (2003): Immigrant settlement and social inclusion in Canada. Working Paper Series- Perspectives on Social Inclusion. The Laidlaw Foundation. http://maytree.com/PDF_Files/SummaryImmigrantSettlementAndSocialInclusion2003.pdf

Papademetriou, Demetrios G./Martin, Phillip L. (eds.) (1991): The Unsettled Relationship: Labor migration and economic development (No. 33). Greenwood Publishing Group.

Paradis, Emily (2012): Experiences of homelessness among women and families with precarious status in Toronto. In: Soheila Pashang (ed), Unsettled settlers: Barriers to integration (pp. 277-298). Whitby, ON: de Sitter.

Picot, Garnett/ Lu, Yuqian/Hou, Feng (2009): Immigrant Low-Income Rates: The Role of Market Income and Government Transfers. Statistics Canada.

Portes, Alejandro/Zhou, Min (2012): Transnationalism and Development: Mexican and Chinese Immigrant Organizations in the United States. In: Population and Development Review 38, 2, pp. 191-220.

Portes, Alejandro (1995): Economic Sociology and the Sociology of Immigration: A Conceptual Overview. In: Portes, Alejandro, (ed.), Economic Sociology of Immigration: Essays on Networks, Ethnicity, and Entrepreneurship (pp. 19-48). New York: Russell Sage Foundation.

Ray, Brian/Preston, Valerie (2009): Are Immigrants Socially Isolated? An Assessment of Neighbours and Neighboring in Canadian Cities. In: Journal of International Migration and Integration 10, 3, pp. 217-244.

Riak Akuei, Stephanie (2004): Remittances as Unforeseen Burdens: Considering Displacement Family and Resettlement Contexts in Refugee Livelihood and Well Being. Is there anything states or organizations can do? Available at: www.unhcr.org

Rose, Damaris (2001): The housing situation of refugees in Montréal three years after arrival: The case of asylum seekers who obtained permanent residence. In: Journal of International Migration and Integration 2, 4, pp. 493-529.

Rousseau, Cecile/Drapeau, Aline/Corin, Ellen (1998): Risk and Protective Factors in Central American and Southeast Asian Refugee Children. In: Journal of Refugee Studies 11, 1, pp. 20-37.

Rue des femmes. (2008) : Mémoire de la Rue des Femmes sur le Phénomène de l'Itinérance au Québec. Brief submitted to the Quebec Commission des affaires sociales. Montreal : La rue des femmes.

Russell, Sharon Stanton (1992): Migrant Remittances and Development. In: International Migration (Geneva, Switzerland) 30, 34, pp. 267-287.

Sandalack, Beverly A./Walsh, Christine/Graham, John R. (2008): Homeless Shelter Design: Considerations for Shaping Shelters and the Public Realm. Calgary: Detselig Press.

Saraswatisi, Jeea (2000): Poverty and Visible Minority Women in Canada. In: Canadian Women Studies 20, 3, pp. 49-53.

Schei, Berit/Dahl, Solveig. (1999). "The Burden Left My Heart": Psycho-social Services Among Refugee Women in Zenica and Tuzla, Bosnia-Herzegovina During the War. Women \& Therapy 22, 1, pp. 139-151.

Schwarzer, R./Jerusalem, M./Hahn, A. (1994): Unemployment, Social Support and Health Complaints: A Longitudinal Study of Stress in East German Refugees. In: Journal of Community \& Applied Social Psychology 4, pp. 31-45.

Smith, J. (2003): L'Intervention et le femmes immigrantes. Montreal: Auberge Madeline. 
Ives, N, Hanley, J., Walsh, C., Este, D. (2014). Transnational elements of newcomer women's housing insecurity: remittances and social networks. Transnational Social Review 4(2-3):152-167

Spitzer, Denise L. (2007): Immigrant and Refugee Women: Recreating Meaning in Transnational Context. In: Anthropology in Action, $14,1 \& 2: 52-62$

Stewart, Alex (1998): The Ethnographer's Method. Thousand Oaks, CA: Sage.

Supporting Communities Partnership Initiative (2003): Best Practices for Working with Homeless Immigrants and Refugees. A Community-Based Action-Research Project. Phase I: Research. Executive Summary. Toronto: Access Alliance Multicultural Community Health Centre. Available via the Virtual Library of the PCERII Metropolis website: http://pcerii.metropolis.net/frameset_e.html.

Teixeira, Carlos (2009): New Immigrant Settlement in a Mid-Sized City: A Case Study of Housing Barriers and Coping Strategies in Kelowna, British Columbia. In: Canadian Geographer/ Le Géographe canadien 53, 3, pp. 323-339.

Teixeira, Carlos/Halliday, Bruce (2010): Introduction: Immigration, Housing and Homelessness. In: Canadian Issues/Thèmes Canadiens Fall, pp. 3-7.

Tischler, Victoria/Rademeyer, Alison/Vostanis, Panos (2007): Mothers Experiencing Homelessness: Mental Health, Support and Social Care Needs. In: Health and Social Care in the Community 15, 3, pp. 246-253.

Valtonen, Kathleen (2012): Social work and Migration: Immigrant and Refugee Settlement and Integration. Surrey, England: Ashgate Publishing.

Van Hear, Nicholas (2002): Sustaining Societies Under Strain: Remittances as a Form of Transnational Exchange in Sri Lanka and Ghana. In Al-Ali, Nadje/Koser, Khalid (eds.), New Approaches to Migration? Transnational Communities and the Transformation of Home (pp. 202-223). London: Routledge.

Vosko, Leah (2006): Precarious employment: Understanding Labour Market Insecurity in Canada. Montreal, McGill- Queen's. University Press.

Walsh, Christine/Hanley, Jill/Ives, Nicole/Hordyk, Shawn-Renee/Mahano, Bora (2011): Uncovering Invisibilities: Understanding Experiences of Newcomer Women Across the Homeless Spectrum. Report prepared for the Homeless Partnership Strategy Human Resources and Skills Development Canada.

Walsh, Christine/Hanley, Jill/Ives, Nicole/Hordyk, Shawn-Renee (Accepted): Understanding the Experiences of Newcomer Women with Insecure Housing in Montréal Canada. Journal of International Migration and Integration.

Walsh, Christine A./Rutherford, Gayle/ Kuzmak, Natasha. (2009): Characteristics of Home: Perspectives of Women who are Homeless. In: The Qualitative Report 14, 2, pp., 299-317.

Walsh, Christine A./Rutherford, Gayle E./Sarafincian, K/Sellmer, S. (2010): Making Meaning Together: An Exploratory Study of Therapeutic Conversation Between Helping Professionals and Homeless Shelter Residents. In: The Qualitative Report 15, 4, pp. 932-47. 